\title{
PANDAN WANGI (Pandanus amaryllifolius Roxb.) LEAVES EXTRACT AS FLIES REPELLENT AND ITS EFFECT ON ORGANOLEPTIC QUALITIES OF CHICKEN MEAT
}

\author{
Arif Ismanto ${ }^{1),}$, Hosni Mubarok ${ }^{1)}$, Fikri Ardhani ${ }^{1)}$ \\ ${ }^{1)}$ Faculty of Agriculture Department of Animal Husbandry, Mulawarman University, Gn. Kelua, Kec. \\ Samarinda Ulu, Kota Samarinda, Kalimantan Timur, Indonesia 75123 \\ *E-mail: arifismanto9@gmail.com
}

Submitted 4 February 2020; Accepted 26 June 2020

\begin{abstract}
The research aims to determine the effectiveness of pandan wangi (Pandanus amaryllifolius Roxb.) leaves extract (PWLE) as flies repellent and understand its effect on the organoleptic qualities of chicken meat. The study was conducted in a completely randomized design with PWLE concentrations $(0,5,10,15$, and 20\%) as research treatments and replicated for four times. The flies repelling data were analyzed by using ANOVA and followed with Least Significance Different (LSD) test. Moreover, the organoleptic test results were analyzed by using Kruskal Wallis test. The results showed that the immersion of chicken meat in PWLE was effective to reduce the number of flies contamination with a repellent level of $0 \% ; 8.25 \%$; $36.5 \% ; 53 \%$ and $59 \%$, on the PWLE addition at $0,5,10,15$ and $20 \%$, respectively. The results of the organoleptic test showed that the PWLE affected the preference of panelists on color, aroma, and texture parameters.
\end{abstract}

Keywords: Chicken meat; pandan wangi leaves extract; repellent; flies; organoleptic 


\section{INTRODUCTION}

Chicken meat is one of animal-based foods that is not only rich of nutrients, but also complete and balanced. However, the chicken is also known to be easily perishable due to physical and chemical factors, as well as microbial activity (Afrianti et al., 2013). Due to its high nutrient content, chicken meat become a popular food, but also become one of the major contributors for food poisoning as the nutrient content also stimulate fast bacterial growth when contaminated.

A food product could be categorized as safe for consumption if harmful compounds are not present, commonly due to the contamination of pathological bacteria, rodents, and even flies. Fly (Musca domestica) is one of disease carriers that could deliver pathological compounds both for human or other animals (Haselton et al., 2015). Pathogenic transmission by this species is mechanical through detection of certain location that is considered attractive by the fly, such as certain spots on human, animals, foods, utensils, and other.

The direct transfer of pathogenic compounds by flies were both through regurgitation of digestive fluids or excretes (De Jesús et al., 2004). Based on survey to chicken meat kiosks in several traditional markets in Samarinda (Segiri, Ijabah, and Pagi markets) that was conducted on September 2018, it is known that flies contamination is a major faced problem. The

*Corresponding author:

Arif Ismanto

Email: arifismanto9@gmail.com

Faculty of Agriculture Department of Animal Husbandry, Mulawarman University, Gn. Kelua, Kec. Samarinda Ulu, Kota Samarinda, Kalimantan Timur, Indonesia 75123 efforts to maintain food quality which fulfills safety, healthy, whole, and halal (ASUH) qualities could be done by practicing prevention, curation, rehabilitation and health promotion to all counterparts. One of the approaches in preventing food contamination could be done by using natural resources, such as pandan wangi (Pandanus amaryllifolius Roxb.) leaves.

The chemical compounds found in pandan wangi leaves include three alkaloid types that initiate biological activities and give certain physiological effects to protect the plant from pest and disease infection (Cheng et al., 2017). Saponin is known as anti-insect agent due to its cellular toxicity that disrupt metabolism of the insect (Singh \& Kaur, 2018).

Pandan wangi also contained polyphenols which disrupt insect digestive capabilities and harm its respiratory tract when combined with saponin. Moreover, pandan wangi contained tannin that precipitates bacterial protein by inactivating the produced enzyme of the bacteria and disrupt bacterial cell wall. There are also other factors that prevent flies contamination on pandan leaves, such as flavonoid that bind protein and act as antioxidant, as well as essential oils that had unfavorable aroma for the insect. In this research, we determine the effectivity of pandan wangi leaves extract to be used as flies repellent and its effect to the organoleptic qualities of chicken meat.

\section{How to cite:}

Ismanto, A., Mubarok, H., \& Ardhani, F. (2020). Pandan Wangi (Pandanus amaryllifolius Roxb.) Leaves Extract as Flies Repellent and Its Effect on Organoleptic Qualities of Chicken Meat. Jurnal Ilmu dan Teknologi Hasil Ternak, 15 (2), 69-77 


\section{MATERIALS AND METHODS}

The research was conducted at the Laboratory of Animal Production and Technology, Faculty of Agriculture, Mulawarman University. The materials used in this research include clean water, distilled water, flies collected around Segiri market in Samarinda, chicken meat obtained from Segiri market in Samarinda, and pandan wangi leaves collected from Bengkuring area in Samarinda that cut from the leaves' $2^{\text {nd }}$ to $5^{\text {th }}$ segment. The tools for analysis include extraction set, weight scale, knife, pan, measuring cup, bucket, scissors, cutting board, hygrometer, thermometer, small fan, flannel cloth, tile cloth, $40 \times 40 \mathrm{~cm}$ glass box, stationery and tools for documentation.

\section{Experimental design}

The research was conducted in a completely randomized design (CRD) with 5 treatments and 4 replications. The treatments included control /without pandan wangi leaves extract (PWLE) immersion (P0); immersed at 5\% PWLE (P1); immersed at 10\% PWLE (P2); immersed at $15 \%$ PWLE (P3); and immersed at 20\% PWLE (P4). In each treatment, 15 flies were randomly placed, so a total of 300 flies were used for all treatments.

\section{Pandan wangi leaves extraction}

The pandan wangi leaves were extracted by following Muhimmah (2014). The extraction was done in the Laboratory of Animal Production and Technology, Faculty of Agriculture, Mulawarman University. The pandan wangi leaves were cut thinly and weighed at $300 \mathrm{~g}$. The leaves were then added with $1 \mathrm{~L}$ of distilled water and heated at $\pm 50^{\circ} \mathrm{C}$ for $5 \mathrm{~min}$. The pandan wangi leaves were then cooled down to room temperature, and filtered with flannel cloth to separate the PWLE and the solid leaves. The PWLE was then diluted with distilled water until reach certain concentrations for research treatments. The detailed dilutions were as follow:

- The 5\% PWLE was obtained by diluting $66.64 \mathrm{ml}$ of PWLE with distilled water until reached $400 \mathrm{~mL}$.

- The 10\% PWLE was obtained by diluting $133.32 \mathrm{ml}$ of PWLE with distilled water until reached $400 \mathrm{~mL}$.

- The 15\% PWLE was obtained by diluting $200 \mathrm{ml}$ of PWLE with distilled water until reached $400 \mathrm{~mL}$.

- The 20\% PWLE was obtained by diluting $266.64 \mathrm{ml}$ of PWLE with distilled water until reached $400 \mathrm{~mL}$.

\section{Sample preparation and immersion}

Chicken meat was used as sample in this research. The sample was immersed on PWLE at different concentrations for $20 \mathrm{~min}$, and placed on $40 \times 40 \mathrm{~cm}$ glass box. As much as 15 flies were then released on the glass box along, and then covered with $60 \times 60 \mathrm{~cm}$ tile cloth for observation.

\section{Flies repellent observation}

The repellent levels were determined by calculating the alighted flies on the chicken meat. The observations were done for $10 \mathrm{~min}$ and repeated for 6 times on each treatment, thus a total of 60 min observation was performed on each treatment. Furthermore, for each 10 min observation, in the first and last minute the flies were driven away from the sample, and the 8 min were to observe whether the flies contaminate the chicken meat. The flies repellent levels of PWLE was then calculated as follows: 


$$
\text { Repellent levels }=\frac{\text { Total flies }- \text { alighted flies }}{\text { Total flies }} \times 100 \%
$$

Source: Aliah et al., (2016).

\section{Organoleptic test}

As much as 20 panelists were included for the organoleptic test. The panelists were consisted of general chicken meat consumers aged at 18 to $35 \mathrm{y}$ old. The assessed organoleptic variables in this research include color, aroma, and texture, scored on 5 hedonic qualities and scales as follow:

- Color, aroma, and texture hedonic scales: 1 = highly favorable; 2 = favorable; $3=$ neutral; $4=$ unfavorable; $5=$ highly unfavorable.

- Color quality: $1=$ green; 2 = yellow green; $3=$ neutral colour, $4=$ light yellow, $5=$ white.

- Aroma quality: 1 = intense pandan leaves aroma; 2 = had pandan leaves aroma, $3=$ neutral aroma; 4 = smelly chicken aroma; 5 = intense smelly chicken aroma.

- Texture quality: $1=$ rough; 2 = slightly rough; 3 = neutral texture; 4 = slightly tender; $5=$ tender.

Table 1. Room temperature and humidity during research

\begin{tabular}{ccc}
\hline Replications & Temperature $\left({ }^{\circ} \mathrm{C}\right)$ & Humidity (\%) \\
\hline I & 27 & 85 \\
II & 27 & 85 \\
III & 26 & 88 \\
IV & 28 & 82 \\
Mean & 27 & 85 \\
\hline
\end{tabular}

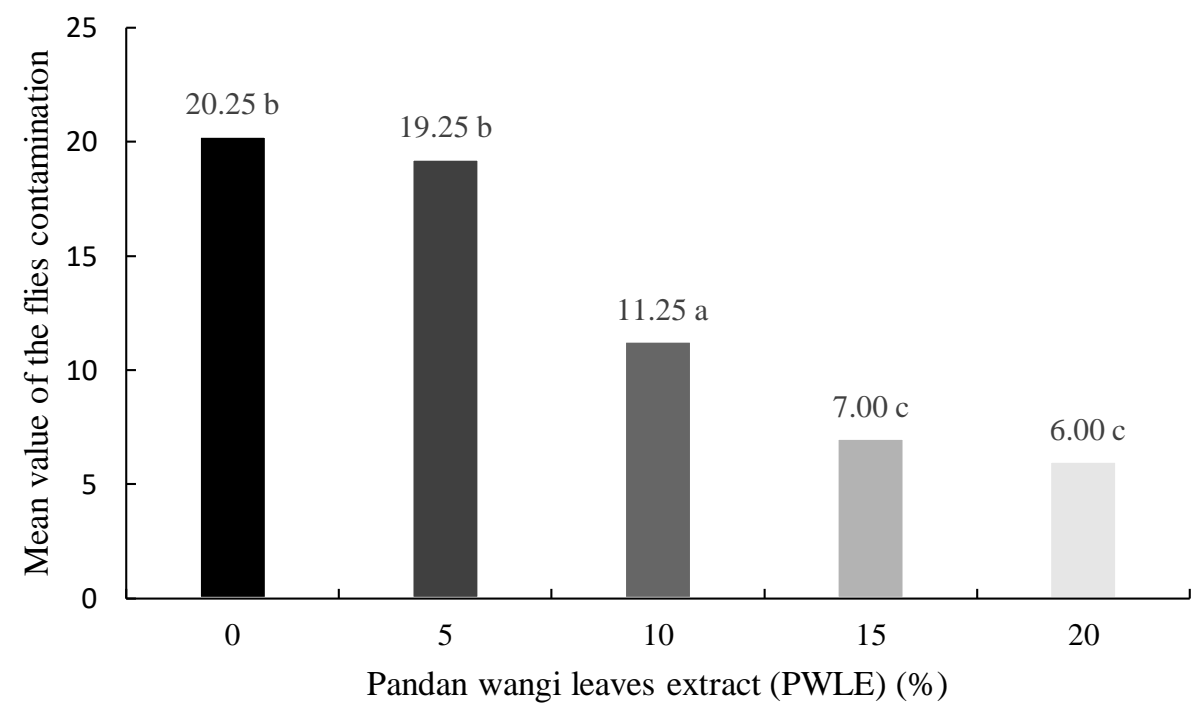

Figure 1. Mean value of the flies contamination on chicken meat Description: Different superscripts indicate significant differences at $5 \%(\mathrm{P}<0.05)$ 


\section{Data analysis}

The data of repellent levels were analyzed using analysis of variance (ANOVA) and followed with Least Significant Difference (LSD) test. The organoleptic data were analyzed with Kruskall Wallis analysis.

\section{RESULTS AND DICSUSSIONS}

\section{Flies repellent levels of PWLE-immersed chicken meat}

The effectivity of immersing pandan wangi (Pandanus amaryllifolius Roxb.) leaves extract at various concentrations $(0 \%$, $5 \%, 10 \%, 15 \%$ and $20 \%$ ) as flies repellent were observed, and the total of alighted flies are presented on Figure 1. The room temperature and humidity on this research were measured by using hygrometer and thermometer (Table 1).

The average room temperature during research was $27^{\circ} \mathrm{C}$ at $85 \%$ humidity. This condition was considered as favorable for flies as according to the standard set by Depkes RI (1992), which showed that flies would be inactive and mostly unable to survive at the temperature below $7.5^{\circ} \mathrm{C}$ and over $45^{\circ} \mathrm{C}$. The flies observation in this research showed that immersion at higher PWLE concentration resulted with significant $(\mathrm{P}<0.05)$ decrease of flies contamination, while lower PWLE concentration resulted with higher flies contamination as well.

The total of alighted flies is one of the important parameters to assess food safety due to flies contamination. Both male and female flies consume fultill their nutrient requirements from various resources, which include human and animal excretes. The mouth structure of the flies requires them to consume liquid or other substances that are easy to be dissolved in their salivary gland. Flies would directly sucks liquid food substances or firstly moisturize the food with its saliva to be consumed (Rozendaal, 1997). Furthermore, Adenusi \& Adewoga (2013) described that there were more than 100 pathogenic compounds that get carried by house flies. These pathogenic compounds could cause diarrhea, anthrax, cholera, dysentery, typhus, and tuberculosis. Moreover, flies could also act as parasites carrier which include $E$. vermicularis, S. stercoralis, T. trichiura and caracanis, Trichomonas, Diphyllobothriam, Hymenolepis, Taenia, as well as Dipylidium.

The result of PWLE immersion as flies repellent is presented in Figure 2. The results showed that the immersion significantly effective as flies repellent $(\mathrm{P}<0.05)$, with 5\% PWLE had repellent levels of $8.25 \% ; 10 \%$ PWLE had repellent levels of $36.5 \% ; 15 \%$ PWLE had repellent levels of 53\%; and 20\% PWLE had repellent levels of $59.7 \%$. The results also showed a positive correlation between PWLE concentration with repellent levels, with higher PWLE concentrations would have higher repellent levels. Hazzard \& Jennings (1936) described that the flies behavior to alight on an area is determined by its sensory nerves, thus the most effective way to prevent flies contamination is to block its sensory nerves through specific aroma. The specific pandan wangi aroma is originated from its monoterpene linalool.

Linalool is a chemical compound commonly found in plant and had intense aroma that is unfavored by insect. Research has shown that linalool, such as in lavender oil, could be used as insect repellent and 
even used as body lotion to repel mosquitos (Marina \& Astuti, 2012).

\section{Organoleptic qualities of PWLE- immersed chicken meat}

The organoleptic qualities of the chicken meat after being immersed on different PWLE concentrations were determined by assessing the color, aroma, and texture of the chicken meat. The results of organoleptic qualities assessment are further described in the following subsections.

\section{Color}

The statistical analysis on the color quality of the chicken meat after PWLE immersion showed a similar color $(\mathrm{P}>0.05)$, but had significant difference $(\mathrm{P}<0.05)$ on its hedonic assessment (Table 2).

Table 2. Hedonic test of chicken meat with different addition levels of pandan wangi leaves extract (PWLE)

\begin{tabular}{ccccccc}
\hline \multirow{2}{*}{$\begin{array}{c}\text { PWL } \\
(\%)\end{array}$} & \multicolumn{2}{c}{ Color } & \multicolumn{2}{c}{ Aroma } & \multicolumn{2}{c}{ Texture } \\
\cline { 2 - 7 } & Hedonic & Quality & Hedonic & Quality & Hedonic & Quality \\
\hline 0 & $2.20 \mathrm{a}$ & $3.81 \mathrm{a}$ & $2.20 \mathrm{a}$ & $3.33 \mathrm{a}$ & $2.59 \mathrm{a}$ & $3.34 \mathrm{a}$ \\
5 & $2.09 \mathrm{a}$ & $3.59 \mathrm{a}$ & $2.68 \mathrm{~b}$ & $3.60 \mathrm{~b}$ & $2.61 \mathrm{a}$ & $3.56 \mathrm{a}$ \\
10 & $2.39 \mathrm{~b}$ & $3.56 \mathrm{a}$ & $2.63 \mathrm{~b}$ & $3.51 \mathrm{ab}$ & $2.88 \mathrm{~b}$ & $3.53 \mathrm{a}$ \\
15 & $2.80 \mathrm{~d}$ & $3.61 \mathrm{~b}$ & $3.23 \mathrm{c}$ & $3.41 \mathrm{ab}$ & $2.80 \mathrm{ab}$ & $3.41 \mathrm{a}$ \\
20 & $2.61 \mathrm{c}$ & $3.60 \mathrm{a}$ & $3.43 \mathrm{~d}$ & $3.66 \mathrm{~b}$ & $2.65 \mathrm{a}$ & $3.44 \mathrm{a}$ \\
\hline
\end{tabular}

Description: (a) Different superscripts indicate significant differences $(\mathrm{P}<0.05)$; (b) Hedonic score for color, aroma and texture are set at 1 to 5 (highly unfavorable to highly favorable); (c) Color quality are scored at 1 to 5 (white to green); (d) Aroma quality are scored at 1 to 5 (intense smelly chicken meat aroma to intense pandan wangi leaves aroma); (e) Texture quality are scored at 1 to 5 (rough to tender)

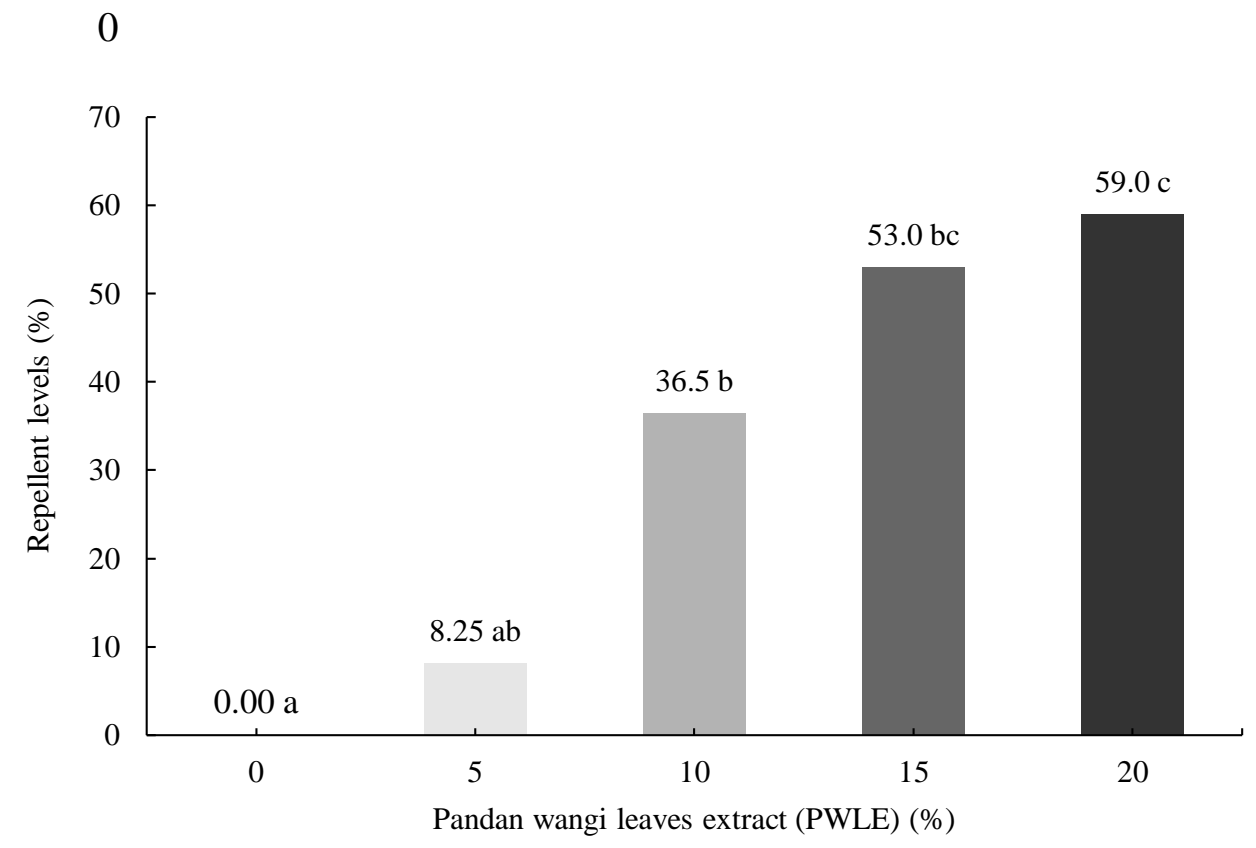

Figure 2. Repellant levels of pandan wangi leaves extract against flies

Description: Different superscripts indicate significant differences at $5 \%(\mathrm{P}<0.05)$ 
The hedonic score of the chicken meat after immersed at all PWLE concentrations in this research were around 4 (favorable), with at $0 \%, 5 \%$, and $10 \%$ PWLE had light yellow color (score: 2 ) and at $15 \%$ and $20 \%$ PWLE had neutral color (score: 3 ).

This showed that the immersion of chicken meat up to $20 \%$ PWLE did not give negative effect to the color of the chicken meat. The PWLE-immersed chicken meat also did not show significant differences to the control treatment.

This was due to the no color attachment of the pandan wangi leaves to the chicken meat, as can be seen that most of the panelists have 2 to 3 score for color. The color assessment is important as food color is known to be affecting factors for consumers acceptability, aside from flavor and nutritional content (Widiastuti, 2008).

\section{Aroma}

The statistical analysis on the aroma quality and hedonic assessment showed that both parameters were not significantly different $(\mathrm{P}<0.05)$ as can be seen in the Table 2. The hedonic score of the chicken meat aroma after immersed with $0 \%$ to $10 \%$ PWLE had smelly chicken aroma (score: 2), while at 15 and 20\% PWLE had neutral aroma (score: 3). However, the hedonic aroma of all research treatments had neutral aroma (score: 3 ).

In this research, it is shown that the immersion of chicken on different PWLE concentration levels contribute to the aroma. Study has shown that the specifically preferable chicken meat should not have intense, smelly and rotten aroma (Ditjen Peternakan dan Kesehatan Hewan, 2012).

\section{Texture}

The statistical analysis on the texture quality and hedonic assessment of PWLEimmersed chicken meat in this research showed that there was no significant difference $(\mathrm{P}>0.05)$ on the hedonic assessment, but showed significant difference $(\mathrm{P}<0.05)$ on the chicken meat structure quality (Table 2). The chicken meat structure that has been immersed on 0 to 20\% PWLE was categorized as slightly rough (score: 2) to neutral (score 3) both for texture hedonic and quality assessment. The meat texture is important for the consumer's acceptability, and it is affected by various factors, such as the age, sex, and stress level of the chicken, as well as the overall rearing management (Perdana et al., 2016).

\section{CONCLUSION}

The research concludes that higher pandan wangi leaves extract (PWLE) resulted better flies repellent levels, and all PWLE concentration levels used in this study did not affect hedonic properties of the chicken meat. The research also showed that the immersion of chicken meat on $20 \%$ PWLE is the most effective approach as flies repellent as seen from the flies contamination levels and organoleptic values.

\section{REFERENCES}

Adenusi, A. A., \& Adewoga, T. O. S. (2013). Studies on the potential and public health importance of non-biting synanthropic flies in the mechanical transmission of human enterohelminths. Transactions of the 
Royal Society of Tropical Medicine and Hygiene. https://doi.org/10.1093/ trstm h/trt095

Afrianti, M., Dwiloka, B., \& Setiani, B. (2013). Total bakteri, $\mathrm{pH}$, dan kadar air daging ayam broiler setelah direndam dengan ekstrak daun senduduk (Melastoma Malabathricum L.) selama masa simpan. Jurnal Pangan dan Gizi, 4(7), 49-56.

Cheng, Y. Bin, Hu, H. C., Tsai, Y. C., Chen, S. L., El-Shazly, M., Nonato, M. G., Chang, F. R. (2017). Isolation and absolute configuration determination of alkaloids from Pandanus amaryllifolius. Tetrahedron, 73(25), 3423-3429. https://doi.org/10.1016/j.t et.2017.05.002

De Jesús, A. J., Olsen, A. R., Bryce, J. R., \& Whiting, R. C. (2004). Quantitative contamination and transfer of Escherichia coli from foods by houseflies, Musca domestica L. (Diptera: Muscidae). International Journal of Food Microbiology, 93(2), 259-262. https://doi.org/10.1016/j.ijf oodmicro.2003.12.003

Depkes RI. (1992). Petunjuk Teknis Tentang Pemberantasan Lalat. Jakarta. Ditjen PPM \& PLP.

Ditjen Peternakan dan Keswan. (2012). Tanya Jawab Seputar Daging Ayam Sumber Makanan Bergizi.

Haselton, A. T., Acevedo, A., Kuruvilla, J., Werner, E., Kiernan, J., \& Dhar, P. (2015). Repellency of $\alpha$-pinene against the house fly, Musca domestica. Phytochemistry, 117, 469475. https://doi.org/10.1016/j.phytoch em.2015.07.004

Hazzard, A. S., \& Jennings, P. J. (1936). A Book of Trout Flies. Copeia. https://doi.org/10.2307/1436393

Marina, R., \& Astuti, E. P. (2012). Potensi daun pandan (Pandanus amaryllifolius) dan repellen nyamuk aedes albopictus potency of Pandanus amaryllifolius and Notophanax scutellarium as aedes albopictus mosquito repellent. Jurnal Kesehatan Lingkungan, 4, 85-91.

Muhimmah, I. (2014). Uji Efektivitas Ekstrak Daun Pandan Wangi (Pandanus amaryllifolius Roxb.) Sebagai Insektisida Nabati Dalam Mengurangi Jumlah Lalat Selama Proses Penjemuran Ikan Kembung (Rastrelliger kanagurta) Asin (Universitas Islam Negeri Maulana Malik Ibrahim).

Perdana, O. S., Riyanti, \& Septinova, D. (2016). Efektivitas tepung bunga kecombrang (Nicolaila speciosa Horan) sebagai pengawet terhadap daya suka organoleptik daging broiler. Jurnal Ilmiah Peternakan Terpadu, 4(1), 19-23.

Rozendaal, J. A. (1997). Vector control and. WHO, Geneva, 17-18.

Singh, B., \& Kaur, A. (2018). Control of insect pests in crop plants and stored food grains using plant saponins: A 
review. LWT - Food Science and Technology, 87, 93-101. https:// doi.org/10.1016/j.lwt.2017.08.077
Widiastuti, D. dan S. (2008). Uji efikasi ekstrak daun babadotan sebagai insektisida nabati terhadap lalat rumah (Musca domestica) di laboratorium. Balaba, 007(2), 7-10. 